\title{
UNDERGROUND SPACE IN ROMANIAN LITERATURE: THE MINE
}

\author{
Carmen DĂRĂBUȘ*
}

\begin{abstract}
The paper analyzes, through some concepts as heterotopy and chirotopy, the meanings of the underground space of mine in Romanian literature from the XX century, space located at the crossroads between reality and imagination, just because the access is difficult, in fusion with the idea of death.
\end{abstract}

Keywords: Romanian Literature, mine, punishment.

The modern and postmodern theories (Michel Foucault, Maurice Blanchot, Gaston Bachelard, Gilles Deleuze, and Peter Sloterdijk) bring various interpretations concerning the analysis of the space, extending his significant. Reflected in literature, the space receives complex meanings, depending on the aesthetic codes of a certain artistic and ideological epoch. The items which compose the space generate images analyzable by concepts as heterotopy (heterotopias) or chirotopia - in my analysis, who is considering the short novel-reportage Moartea lui Iacob Onisia (The End of Iacob Onisia) by Geo Bogza - where the social content prevails, the novel The Archangels wrote by Ion Agârbiceanu - the moral alterations of the peoples around a mine gold field, the Augustin Buzura's novel, Drumul cenuşii (The Road of Ashes) - where the ideological content prevails, and the novel Cel mai iubit dintre pământeni (The Most Beloved Earthling) by Marin Preda - which transgresses the anterior thanatic significances by a politic-punitive semantic layer.

The space, situated at the interference of the reality with imagination, produced various types of imagination, signs of material elements, distinguished through topo-analyze. ${ }^{1}$ Through the similarity with the House, to which we relate, usually, through topophilia, the workplace outside of home it is another important topos; if intimate environment (home) is our creation, working environment (in the case of our analysis, the mine) is one who exercises influence over us, more than we are exercising over him, especially when it involves a large number of individualities.

\footnotetext{
* Assistant Professor PhD, Faculty of Letters, Baia Mare, Technical University of ClujNapoca / I.L.R. / „St. Kliment Ohridski” University of Sofia (carmen.darabus@cunbm.utcluj.ro).

${ }^{1}$ Gaston Bachelard, Poetica spațiului, Ed. Paralela 45, Pitești, 2005.
} 
Maurice Blanchot defines literary space as a place "where everything must take place-for everything to be described as simultaneity in pictures" (Blanchot 1980: 268), so that the multi-stratification space should be in plain sight, even if the images plans close and distant are a lot and divers positioned.

Michel Foucault's theories concerning the space operate a distinction between utopia and heterotopias; if the first one has no reflection in the real world, the second one suppose "real places, actual places, places drawing even in the process of society's establishing, and who are a kind of againstplacement, a kind of utopias concretely realized, where the real emplacements [...] are at the same time represented, contested and inverted some species of places outside of any place, even if they are effectively localizable" (Foucault 2001: 253). Heterotopias, in turn, are depicted as crises (places or taboo places for persons which are, either temporarily, in a dysfunctional relationship with society), and deviation (prisons, cemeteries, psychiatric hospitals). The constituent elements of the space generate images analyzable in the heterotopology concept. Intrusion into heterotopias relies on a ritual that includes, at the ends, closing and opening; the mine as a place where social control is relativized because of isolation, may constitute such heterotopias, which becomes mental space, then literary space. In the world literature, she is entering in 19th century, in the works of E. T. A. Hoffmann's novel - The mines of Falun, and Emile Zola's novel Germinal.

In the tradition of Transylvanian moralistic prose - as temporal segment, between Ioan Slavici ${ }^{2}$ and Liviu Rebreanu ${ }^{3}-$ it is situated Ion Agârbiceanu, in our subject of analyze with the novel Arhanghelii (The Archangels), whose action is situated at the beginning of the 20th century in the gold mines at Apuseni Mountains. The mine becomes a central reality as in the Zola's novel, Germinal, She orders the destinies of men in relation to gold found in galleries, dehumanizes the peoples characters, detects social vices in a key of analyze classic-realistic. The story of former notary Iosif Rodean, became director of the golden mine The Archangels in Văleni, is emblematic for the destiny of many gold-seekers: enriched, detached from the social class to which he belonged, then drying up the source of income provokes a collapse in all aspects: financial, social, psychological - no power to redress because it had come to identify with the prosperous miner. In a didacticism contrast, is narrative profiled the priest's family Murășanu, having the right guide the holy books and the ancient morality. Realistic evocation is matched by the folk one, by the stories about Vâlva Băii ${ }^{4}$, entity

\footnotetext{
${ }^{2}$ The second part of of XIX century.

${ }^{3}$ The first part of XXth century.

${ }^{4}$ It is a mythical female character who appears in the legends from Apuseni Mountin; she is the spirit of gold mine and show up to the miners ' only honest. It showed, according to
} 
announcing, according to the ancestral beliefs, the drying up or the prosperity of a well mine. The death is announced of this female spirit from another world. But death itself has known meanings of the mining community:"The Archangels kill many people, said the servant. The miners are thinking that they will found a lot of gold. But I say that it isn't a good sign" (Agârbiceanu 1998: 30). Swirling, unpredictable dug since Roman times, absorb, like a funnel hell even experienced miners. Ten years of mining gold field had turned an agricultural population into uncertain one, neither urban nor rural, which now buys all the foods they once produced in individual households. The type of work generates a certain kind of psychology, in which the abduction replaced the joy of the harvest: "The work in the bosom of the earth it's heavier and bitterer. Here are not looking for anyone to collect the fruits of a seed thrown to them, but almost everything rests on chance, on random. It's not a job, it's a hunt. They are searching for with ardor assailed with mallets, breaks rock and, if after much toil in dark and smell of the pit, finding gold, they are unable to collect, but it greedily kidnapping" (Agârbiceanu 1998: 57). If the work at the Earth's surface binds man's life, that of his squabbling calls him to death; changing the agricultural avocations with the mining one operating as an unconscious form of election of the death at the expense of life. Signs of habits changes are not good for the outside observer, as the young student in theology, Vasile Murășanu:"- Great wealth makes people scoundrel [...]. This mine it is a malediction for the village" (Agârbiceanu 1998: 39). On holidays, it be observed also this process of these behavioral mutations, because instead of effusive manifestations of yore, they prefer a reserved attitude, their temper becoming "dark and cold as in the bosom of the Earth where they spent life" (Agârbiceanu 1998: 367). Every family that has a working miner gone is waiting with some anxiety his return, and any sudden news brings the death blast, as any delay increases gradually the anguish. The Gligoraș's death is going over the festive period, such as that of Iacob Onisia, the character from the Geo Bogza's novel. Entered inside a gallery without the knowledge of the owner of the mine gold field, he is found collapsed in a whirlwind, after three days of absence. Unidentified noises coming from the depths are attributed to Vâlva Băilor, who warns of the approach of some misfortune. The sight of his corpse would overshadow to Iosif Rodean a single exclamation: “-Hey, poor man, now you have enough of gold!", and others miners was looking his unfortunate death as a crime of the mine

popular tradition, in the form of a beautiful fairy or an old man with white beard, which led him on to a place in mine where was gold. 
when he was working honestly" (Agârbiceanu 1998: 120, 123), not when he was stealing in a thieving way. Death in mine leveled any moral shades. As the soldiers and sailors during the war, with the threat of death near, miners enjoy and work with the same fierce desperation. The exhaustion of gold deposits brings death, because in desperation to pull out the gold, it is ordering unsuspecting dynamite explosion, and „Visa, Ghiuţ, Părău și Petrișor have died. [...] They were broken into hundreds of pieces as soon the detonation occurred" (Agârbiceanu 1998: 254). Once mostly drained gold reserves of the mine 'Archangels', the main shareholder Iosif Rodean, indebted to the banks, unable to adapt to the new realities, retreats into the house as in a mine-tomb.

Geo Bogza's novella-reportage, Moartea lui Iacob Onisia (The End of Iacob Onisia), brings a tragic moment of the life miners from Jiu Valley, namely the accidental death of a miner collapsed on a cable-car. In the middle of winter, in Christmas Eve, Iacob Onisia tries to get faster in the bosom of the family and, as in other times, climbs on the sly on the cablecar that does not carry the miners, ignoring the fact that, being a public holiday, it may be turned off. Exhausted by cold, hunger, waiting, he is trying to descend on cable until the next pillar, but the weakened forces doesn't allow the submission of more than a few meters and plunges into ravine. The news, although shudder labor colonies, is not surprising: "What was not possible in that Valley in which had taken place so many misfortunes and disasters?" (Bogza 1979: 4). Punished with moving, weather two months, from Aninoasa to Petrila, because he entered drunk in mine (without producing, in fact, no problems, with the exception of infringement), crossing daily, the hills and the valleys, up comes the idea to use a cable-car truck, without to be seen by the line controller, to shorten the way in cold and slush. Seven weeks was gone hardly, Onisia was supported by the thought that it have left very little of expiation. At the entrance of mine had begun the Christmas little trade, practiced by elderly women selling fruit and sorcove ${ }^{5}$. In front of the mine gallery, the miners' salutation, "Good luck!" sounds of incantation meant to take them out unharmed back to light: "In front, they always had the hard and black wall of the coal, but through their minds always passed pieces of red meat, as they saw at home in large wooden bowl, and in that moment they handled hammers with an accelerated strain, almost with anger; large dollops of coal fall down, at their feet" (Bogza 1979: 11). The paradox of death is the fact that he not arrive to die inside of mine, but outside, crashed in the gap of a nature as hostile as the world galleries, nature transformed in a "polar area", where the very near feast "immense and sad" brigs just some extra-food. As

\footnotetext{
${ }^{5}$ Traditional objects, a twig adorned with artificial flowers of different colors, used by children in the morning of New Year's Eve, wishing health.
} 
in Dante's Inferno, colors, sounds, smells are mixed in a synesthesy of death: "So it happens in mine when the methane burst into flame. The trucks' rails are plucked from the Earth and twisted in the air. The galleries are full of death people, with hair and clothes burned, and from time to time the corpse of a death horse hampers the road" (Bogza 1979: 15). Fear of death is often dissimulated in aggressive behaviors, in alcohol abuse.

In the Augustin Buzura's novel, Drumul cenuşii (The Road of Ashes), the mine reality is less specified; here is prevailing a lifestyle of mining areas. The initiation itinerary of the journalist Adrian Coman start in the mining town in the North of the country, River Lady, in other mining towns (Măgura, Stoinița, Marginea), travel which does not include the incursion in a mine, but in realities generated by this one, in different social segments. The search of the engineer Helgomar David disappeared in unclear circumstances, after he distributed the politico-ideological regime of this time period is, equally, the search for oneself, a confrontation with his cowardice and with the pusillanimity's of the others. Environment generator of the insecurity creates special kinds of behavior, because the neighborhood of death causes the anguished only apparently suppressed: "Our job is difficult and dangerous, full of unexpected things, so often I am asking myself, especially in the morning, when I am entering in mine, if I will see it next day?" (Buzura 1992: 34),"And it's not too pleasant to work in an old mine, reopened, that do not lend themselves to great upgrades"(Buzura 1992: 36) or "And the miners have a special sense of death, more developed than anyone ..." (Buzura 1992: 254). Love stories that intersect in the novel speak also about honor and dissimulation, about perseverance and cowardice, in a political frame with easy-to-decipher allusions to the Communist ideology of the epoch, which turns in bad or in well, the individual loosed in the social and personal maze, sprinkled with danger and taboos.

Mine is not foreign at all the idea of underground space island, to the extent that the concept of insularisation has expanded much significance. Gilles Deleuze sees the island as a native area representing in small-scale the vast expanse land: „L'île est le minimum nécessaire à ce recommencement, le matériel survivant de la première origine, le noyau ou l'œuf irradiant qui doit suffi à tout reproduire"6 (Deleuze 2002: 11); likewise, mine, as the core of his life underground reproduces the idea of gaining space to bring to the surface the riches. Peter Sloterdijk, in its classifications relating to insularized space $^{7}$, talks about anthropogenic Islands that, in turn, have some sub-classifications; some of these, in the chirotope definition, its available for mine - that is to say an area obtained

\footnotetext{
6 "The island is the minimum required of the beginning, the initial material, the radiant core egg enough to reproduce".

${ }^{7}$ Peter Sloterdijk, Sphères III, Ecumes, Maren Sell Editions, Paris, 2005.
} 
by using the hand of man, a world of human activity which may affect the environment in various ways; connected to chirotope, in the space strongly marked ideological, that gets a real punitive space (as the mine is in the Marin Preda's novel Cel mai iubit dintre pământeni - The Most Beloved Earthling), it is the Sloterdijk definition for ergotope, in sensus communis dimension, caused by parental or religious authority, in this case a political authority. Form of the Gulag, mine as a detention place justifies the Ruxandra Ceseranu's claim: "If at the beginning it was an object of study, he became in time a narrative structure and he created a style" (Cesereanu 2005: 82). Marin Preda's novel Cel mai iubit dintre pământeni - The Most Beloved Earthling transgress the previous thanatic meanings, from the Geo Bogza and Augustin Buzura's literature, through a semantic punitive layer. Victor Petrini, the main character of the novel is a victim of political purges in the ' 50's of the past. Kicked out of University where he holds the position of Assistant Professor at the Department of philosophy, he is sentenced to three years in prison, became forced labor, one of which at the Mine of Baia Sprie, mine extraction of lead. Without being an overtly protester in relation to new so-called popular established. He is suspected, by error, to collaborate with the extremist organization Sumanele negre (Black Coats). The detention story and the socio-occupational marginalization it is matched by the erotic-family and drama that he lives next to Matilda, the detention only deferring the inevitable separation. Human mosaic mine is the typical for communist prisons - a mix of biographies of an unsuccessful social heterogeneous composition: former dignitaries of the earlier period of the new political regime under Stalin's influence, but ordinary thief, also. In the middle of darkness from galleries, evil takes hallucinatory proportions, human nature amplifies its destructive instincts and the instinct to kill becomes a form of liberation. Hideous guardian which propose to exterminate Victor Petrini no apparent reason, it is murdered and thrown into the abyss of an galleries, after fails the attempts to kill the prisoner in lockup and places of travel. Crime, in fact, self defense, do not provokes to Petrini qualms of conscience; looking at him, in sequence, the hatred of an eye," the thought of killing it has been planted in me with overwhelming force; when it was realized I've never felt more a so strong freedom feeling (Preda 1984, II: 59). It seems the work suddenly easier, despite of the sixteen hours a day, when he is pushing boulders lead for trucks-car. The feeling of merging with death, once he is ready to die, but he kills before being killed, it is, paradoxically, liberator, because now Petrini knows directly the death: "Even death around which we'd work moment-by-moment (because always could detach from the vault of the

\footnotetext{
${ }^{8}$ Organization (1944-1946) founded by the ex-officers of Romanian Royal Army and by legionnaires (radical nationalists) having as aim to fight against communists.
} 
mine and stomp large pieces of ground displaced by the noise of perforators, as it happened before, crushing on some of us) gave to moments a twinning with this vault, as happens in war when a strange feeling of sympathy is born between beating heart that hears whistling sound it makes the bomb and bomb itself [...]" (Preda 1984, II: 59). The inside hell it is doubled by an outside one; galleries and old elevators from the Franz Josef epoch give the impression that every day in the mine may be the last day of life. Black dust covered everything, even the intimate areas of the body, but there's another type of invasion: "As with any camp, every ten prisoners had an informer" (Preda 1984, II: 61), which control everything. Mine effects of lead are extended after release, too - a supervised freedom - typical for dictatorships and for societies with no real and long exercise of democracy - because a disease of the respiratory system will keep him, for a while, in a hospital in his hometown.

So insular space and insularisation extend much their significance in the modern and post-modern period, because "islands can be any of the forms of isolation: geographical areas (Islands, oases, mountains, etc.), social areas (the monastery, hospital, prison, ghetto, etc.), individual etc." (Răcaru 2000: 1) - the mine being a social one. Thanatic space, insular carceral space in oppressive ideological systems, the mine gets to dominate mentalities and behaviors in communities around.

\section{References}

Agârbiceanu, Ion (1998). Arhanghelii, București: Editura 100+1 Gramar. Ediție, prefață, curriculum vitae și bibliografie de Constantin Mohanu.

Bachelard, Gaston (2005). Poetica spațiului, Pitești: Editura Paralela 45. Traducere de Irina Bădescu și Prefaţă de Mircea Martin.

Blanchot, Maurice (1980). Spațiul literar, București: Editura Univers. Traducere de Irina Mavrodin.

Bogza, Geo (1979). Priveliști și sentimente. Moartea lui Iacob Onisia, București: Editura Albatros, Prefață, tabel cronologic și referințe biobibliografice de Antoaneta Tănăsescu.

Buzura, Augustin (1992). Drumul cenuşii, București: Editura Fundației Culturale Române. Ediţia a doua.

Cesereanu, Ruxandra (2005). Gulagul în conștiințta românească. Memorialistica și literatura inchisorilor și lagărelor comuniste. Eseu de mentalitate, Iași: Editura Polirom.

Dărăbuș, Carmen (2014). Mina ca spaţiu literar thanatic în Susret kultura Encounter of Cultures, Zbornik radova, Univerzitet $\mathrm{u}$ Novom Sadu, Filozofski fakultet.

Deleuze, Gilles (2002). L'île déserte et autres textes, Paris: Edition Minuit. 
Foucault, Michel (2001). Theatrum philosophicum, cap. „Altfel de spații”, ClujNapoca: Editura Casa Cărții de Știință. Traducere de Bogdan Ghiu - partea I și de Ciprian Mihali, Emilian Cioc, Sebastian Blaga - partea a II-a.

Preda, Marin (1984). Cel mai iubit dintre pământeni. Vol. I-II-III, București: Editura Cartea Românească. Ediția a doua.

Răcaru, Roxana (2000), „Despre insularitate ca spațiu central” în revista „România literară”, București, 20/2000.

http://www.romlit.ro/despre insularitate ca spaiu central

Sloterdijk, Peter (2002). Sphères I, Bulles. Paris: Edition Pauvert.

Sloterdijk, Peter (2005). Sphères III, Ecumes. Paris: Edition Maren Sell Editions. 